\title{
Effects of Nitrogen and Sulfur Sprays on the Growth and Production of Broccoli Brassica Oleracea var. Italica L.
}

\author{
Mushtak F. Karomi Kisko ${ }^{1^{*}}$ \\ Nabil Jwad Kadhum ${ }^{2}$ \\ Zainab Anwar Ali ${ }^{1}$ \\ Noora Saheb Abid ${ }^{3}$
}

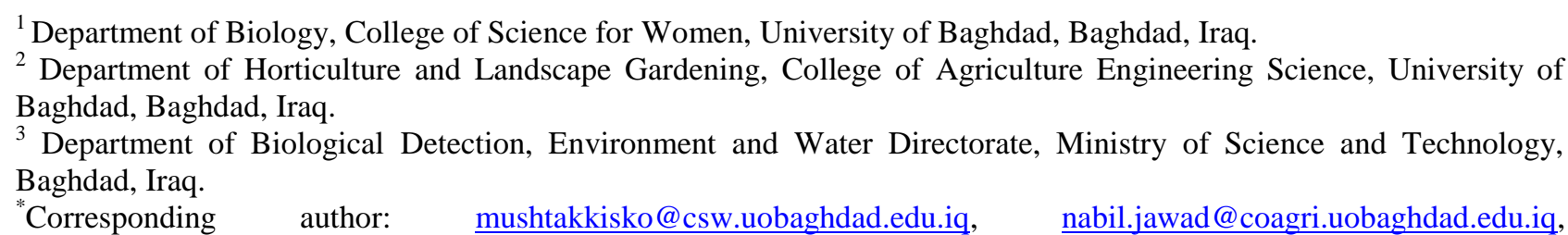
zainab.anwar@csw.uobaghdad.edu.iq, noorag79@gmail.com

"ORCID ID: https://orcid.org/0000-0001-9676-1477", https://orcid.org/0000-0003-1001-4783.

Received 22/11/2020, Accepted 13/12/2020, Published Online First 21/2/2021, Published 1/9/2021

This work is licensed under a Creative Commons Attribution 4.0 International License.

\begin{abstract}
:
In order to achieve optimal plant growth and production, essential nutrients must be readily available in adequate quantities and in a balanced proportion to give a good yield, especially broccoli which has health benefits that may not be found in many other plants. For this purpose, this experiment was carried out during the seasons 2019/2020 in the botanical garden of the Department of Biology, College of Science for Women, University of Baghdad, to study the effects of nitrogen and sulphur and their interaction on eight parameters reflecting the overall traits of vegetative growth, yield, and chlorophyll content of broccoli Brassica oleracea L. (var. italic JASSMINE F1 Hybrid). A factorial design with three replicates was used, each with 7 plants treated via foliar spraying. The first factor included three groups; control N0 (distill water spray), N1 (500 mg. $1^{-1}$ nitrogen), and N2 (1000 mg..$^{-1}$ nitrogen). The second factor also included three groups; control S0 (distill water spray), S1 (500 mg. $\mathrm{l}^{-1}$ sulfur), and S2 (1000 mg. $\mathrm{l}^{-1}$ sulfur). We used Urea $\left(\mathrm{CO}\left(\mathrm{NH}_{2}\right)_{2}\right)$ as a nitrogen source and zinc sulphate $(\mathrm{ZnSO} 4)$ as a sulfur source. As for the treatment with nitrogen, the results revealed that $\mathrm{N} 2$ treatment caused the significantly highest values in all the studied traits, except for the plant height, where there was no significant difference between N1 and N2. As related to the treatment with sulphur, the results showed that S2 treatment resulted in the significantly highest values of leave area, leave dry weight, and root fresh weight. S2 also caused the highest values, but with no significant differences, of plant height, stem diameter and chlorophyll content index. S1 treatment, on the other hand, caused insignificantly higher values of leave number per plant and main curd weight. Based on the results of the interaction between nitrogen and sulfur, S1N2 treatment resulted in the significantly highest values as compared to all other treatments of all the studied traits, except for the plant height, root fresh weight, and main curd weight. The results presented here may facilitate improvements of Broccoli cultivation with suitable nutrient concentrations for sustainable agriculture. In conclusion, the present study comes up with the following: nitrogen and sulfur and their interaction enhance significantly the growth and production of broccoli.
\end{abstract}

Keywords: Brassica oleracea, Broccoli, Foliar application, Nitrogen, Sulfur.

\section{Introduction:}

Broccoli (Brassica oleracea L. var. italica), which belongs to family Brassicaceae and genus Brassica, is a fast-growing annual and herbaceous vegetable crop (1). According to FAO statistics in 2018, the production of broccoli, including cauliflowers, reached more than 26.5 million metric tons, while the production in Iraq was 11.2 thousand metric tons (2). These data imply that the local production of this plant in Iraq comprises less than $0.4 \%$ of the global production. The reasons behind this low production level are probably that the plant 
is only recently cultivated and is still grown in very limited and scattered areas in Iraq.

Broccoli consumption is rising worldwide because it is considered as an integral part of a healthy diet, being a very excellent sources of biological active compounds, such as sulforaphane, glucosinolates, and isothiocyanates. Broccoli is also rich in vitamins $\mathrm{A}, \mathrm{B}, \mathrm{C}$ and $\mathrm{K}$, as well as minerals, including phosphor, potassium, manganese, calcium and Iron. The plant also has higher content of the dietary fiber, carotene, which is good for health and conscious diet $(3,4,5)$.

Macronutrients such as nitrogen and sulfur play important roles in supporting the processes of plant growth and development, leading to an increase in the overall yield (6).

It was previously reported that nitrogen application positively affects the head weight in broccoli floral parts (7). Also it was confirmed that the growth and the total and marketable yields were increased significantly with the increase of nitrogen supply on broccoli (8). Likewise, another study (9) found that a general increase in harvest index with increasing nitrogen rate reflected a stronger effect of nitrogen on the head yield than on the total above ground biomass production.

Furthermore, an earlier work (10) showed that chlorophyll content of wheat leaves was highly correlated with their nitrogen and sulfur concentrations, while another report (11) indicated that chlorophyll content was increased with increasing the application of nitrogen on broccoli leaves.

On the other hand, increased addition of sulfur on broccoli resulted in an increase in leaves fresh weight, curd diameter, and height (12). Other authors (13) reported that plant height, number of leaves, and head yield, were increased with adding sulfur to broccoli plants. Treatments containing sulfur were also shown to increase broccoli yield up to $14 \%$ (14).

Moreover, a number of reports showed significant interactions between $\mathrm{N}$ and $\mathrm{S}$ availability, causing positive effects on the plants. For example, the interaction between sulfur and nitrogen was shown to increase leave blade, whole plant and total biomass of Brassica napus L. (15). Also sulfur and nitrogen, separately and in interaction, affected broccoli floret yield (16).

The beneficial effects of foliar urea applications, expressed as an increase in yield and an improvement of crop quality, were reported in many vegetable species such as cabbage, onion, cucumber, and squash (17). The spray of sulfur and nitrogen significantly affected the curd yield of broccoli, both separately and as a combination.
Despite the growing interest in foliar fertilizers, there is still little information on the effects of the foliar application on broccoli. However, some studies showed that foliar fertilization is more economical, efficient, and rapid, along with its higher safety and independence of soil conditions (18). After the crop is harvested, large amounts of residues are left in the field, being about 80 percent in broccoli (19). At optimum nitrogen application, around $100-120 \mathrm{~kg}$ per has remained in the crop residues of cauliflower and about $50-80 \mathrm{~kg}$ per ha in the $0-60 \mathrm{~cm}$ layer of the soil (20).

To our knowledge, there is a lack of research, particularly under field conditions, to show the effects of fertilizers on growth and yield of this novel product in the Iraqi environment. It is also already established that of the provision of mineral fertilizers via the spraying method has superior effects on growth, development and yield productivity of plants.

The aim of the present study is to evaluate the influence of foliar spray of nitrogen and sulfur on the growth and yield of the curd of broccoli in the local environment, taking into account especially the growing demand for this plant in the Iraqi market.

\section{Materials and Methods:}

This experiment was carried out during the growing season 2019-2020 in the botanical garden of the Department of Biology, College of Science for Women, University of Baghdad. A factorial design with three replicates was used. The first factor included three groups; control N0 (distill water spray), $\mathrm{N} 1$ (500 mg. $\mathrm{l}^{-1}$ nitrogen), and N2 (1000 mg. $1^{-1}$ nitrogen). The second factor also included three groups; control S0 (distill water spray), S1 (500 mg. ${ }^{-1}$ sulfur), and S2 (1000 mg. $\mathrm{l}^{-1}$ sulfur), as a result, it became nine treatments, identical to combinations of nitrogen and sulfur foliar spray. Each treatment included 3 replicates, each containing 7 plants. The leaves were sprayed with solutions of distilled water containing $0.1 \%$ Tween 20 (polysorbate 20, which is a polysorbatetype nonionic surfactant formed by the ethoxylation of sorbitan) as surfactant. We used Urea $\left(\mathrm{CO}\left(\mathrm{NH}_{2}\right)_{2}\right)$ as a nitrogen source and zinc sulphate ( $\mathrm{ZnSO} 4)$ as a sulfur source.

The experimental unit was represented by 1 $\mathrm{m}$-apart and $3 \mathrm{~m}$-long furrows, each containing 7 plants, $45 \mathrm{~cm}$ apart. During the period of plantgrowing, furrow irrigation was used regularly and weeds were kept under control manually. The soil of the research area was clay loam. Broccoli Brassica oleracea L. var. italic JASSMINE F1 Hybrid (from DELTA seeds, Holland) cultivars, 
with seedlings of 4 true leaves, were transplanted in an open field on the third of October 2019. At curds collection (harvest), seven plants were randomly chosen for experimentation. The leaves of plants were sprayed with nitrogen and sulfur twice, the first time after the formation of the five leaves, on October 25, 2019, and the second when the flowering discs began to form, on December 15, 2019.

The following parameters for growth and yield characteristics were recorded on randomly selected plants: plant height $(\mathrm{cm})$, leaves weight (gm), number of leaves per plant, leaf area $\left(\mathrm{dm}^{2}\right.$.plant $\left.{ }^{-1}\right)$, plant stem diameter $(\mathrm{cm})$, fresh root weight $(\mathrm{gm})$, and weight of the main curd (gm). In addition, chlorophyll content index (CCI) was determined with a portable chlorophyll meter (OPTI-SCIENCES model CCM-200 plus / USA) at optical absorbance of $633 \mathrm{~nm}$ (Chlorophyll) and $931 \mathrm{~nm}$ (Near Infra-Red) (21).

For the statistical analysis, the analysis of variance (ANOVA) was performed on the analytical data to examine the effects of foliar spray with nitrogen, sulfur, and their interactions on growth and yield of broccoli. Least significant difference
(LSD) test was used for mean comparisons at $p<$ 0.05. Data were analysed using SAS software (SAS Institute, Cary, NC, USA).

\section{Results:}

Data in Table 1 show that spraying nitrogen and sulfur increased the height of broccoli plant, with values of $66.41 \mathrm{~cm}$ for $\mathrm{N} 2$ and $65.37 \mathrm{~cm}$ for S2 treatments. However, there were no significant differences between both $\mathrm{N} 1, \mathrm{~N} 2$ and $\mathrm{S} 1, \mathrm{~S} 2$ treatments. Meanwhile, the interaction between these treatments resulted in higher values of plant height, compared with the control $(53.14 \mathrm{~cm})$, reaching a highest value of $71.05 \mathrm{~cm}$ when N2 and S1 treatments were combined.

As shown in Table 2, the results showed a significant increase in the mean stem diameter following $\mathrm{S} 2(3.18 \mathrm{~cm})$ and $\mathrm{N} 2(3.2 \mathrm{~cm})$ treatments compare to S0, N1 and N0. Nevertheless, there was no significant difference between $\mathrm{S} 1$ and $\mathrm{S} 2$ treatments, whereas the interaction of S1N2 led to an increased mean stem diameter $(3.44 \mathrm{~cm})$ compared with the control $(2.71 \mathrm{~cm})$.

Table 1. Effects of nitrogen and sulfur levels and their interaction on broccoli height $(\mathrm{cm})$ during 2019/2020.

\begin{tabular}{|c|c|c|c|c|c|}
\hline Treatment & S0 & S1 & & S2 & N Mean \\
\hline No & 53.14 & 56.19 & & 60.33 & 56.65 \\
\hline N1 & 57.56 & 68.75 & & 68.51 & 64.94 \\
\hline N2 & 60.90 & 71.05 & & 67.29 & 66.41 \\
\hline S Mean & 57.20 & 65.33 & & 65.37 & \\
\hline L.S.D. 5\% & & & $S=1.89$ & & \\
\hline
\end{tabular}

Table 2. Effects of nitrogen and sulfur levels and their interaction on stem diameter $(\mathrm{cm})$ of broccoli during 2019/2020.

\begin{tabular}{|c|c|c|c|c|}
\hline Treatment & So & S1 & S2 & N Mean \\
\hline No & 2.71 & 2.89 & 3.14 & 2.91 \\
\hline N1 & 2.84 & 3.24 & 3.23 & 3.10 \\
\hline N2 & 2.91 & 3.44 & 3.21 & 3.18 \\
\hline S Mean & 2.82 & 3.19 & 3.2 & \\
\hline L.S.D. 5\% & & & & \\
\hline
\end{tabular}

The results in Table 3 clearly indicate that adding nitrogen led to significantly increasing the leaves number per plant for N2 treatment (24.49) compared with N0 (21.95). Similar results were observed with sulfur, which recorded 24.05 leaves for S1 treatment compared with 22.09 leaves for S0. However, there was no significant difference between $\mathrm{S} 1$ and $\mathrm{S} 2$ treatments. In addition, the interaction between $\mathrm{N}$ and $\mathrm{S}$ treatments showed an increase in the leaves number to 25.05 for S1N2 compared with 20.62 for SONO.
In the same context, we found that the leaf area was increased significantly due to the increase in nitrogen and sulfur addition, showing values of $83.22 \mathrm{dm}^{2}$.Plant ${ }^{-1}$ for $\mathrm{N} 2$ and $81.21 \mathrm{dm}^{2}$.Plant ${ }^{-1}$ for S2 compared with $72.25 \mathrm{dm}^{2}$.Plant ${ }^{-1}$ for N0 and $71.96 \mathrm{dm}^{2}$.plant ${ }^{-1}$ for S0. Mean leaf area values showed higher increase as a result of the interaction between nitrogen and sulfur, reaching 87.19 $\mathrm{dm}^{2}$.Plant ${ }^{-1}$ for $\mathrm{S} 1 \mathrm{~N} 2$ treatment compared with $68.33 \mathrm{dm}^{2}$.plant ${ }^{-1}$ for the control Table 4 .

In the same context as the previous result, the results in Table 5 reveal significant increases in 
the leaves dry weight when sprayed with nitrogen and sulfur elements, with mean values of $134.86 \mathrm{gm}$ for $\mathrm{N} 2$ and $128.21 \mathrm{gm}$ for S2, compared with $106.45 \mathrm{gm}$ for N0 and 106.27 for S0. Furthermore, the interaction between the two treatments caused the highest increase in the dry weight of the leaves, which was $147.72 \mathrm{gm}$ for S1N2 compared to 94.38 gm for the control.

The results in Table 6 reveal that root fresh weight was significantly increased by spraying nitrogen and sulfur, with values of $118.89 \mathrm{gm}$ for $\mathrm{N} 2$ and $122.53 \mathrm{gm}$ for S2. In addition, the overlap between these two elements led to the highest dry weight value $(124.99 \mathrm{gm})$ for the treatment S1N2, while the value for the control was $101.59 \mathrm{gm}$.

Regarding the effects of nitrogen and sulfur spray on plant's chlorophyll content index, data in Table 7 show that $\mathrm{N} 2$ and S2 treatments resulted in the highest values (60.57 and 55.93 respectively), while there was no significant difference between S1 and S2 treatments. As related to the overlap between treatments with these elements, a significant increase in mean CCI value was found following S1N2 treatment (64.84) compared with the control (39.41).

Data in Table 8 show that nitrogen and sulphur application with $1000 \mathrm{mg} \cdot \mathrm{l}^{-1}$ significantly increased the main curd weight, with mean values of $478.92 \mathrm{gm}$ for $\mathrm{N} 2$ and $476.43 \mathrm{gm}$ for S1, while there was no significant difference between S1 and S2 treatments. However, the data reveal that the interaction between nitrogen and sulfur caused significantly higher values, as demonstrated by S1N2 treatment $(491.91 \mathrm{gm})$ compared with S0N0 treatment (376.46 gm).

Table 3. Effects of nitrogen and sulfur levels and their interaction on leaves number of broccoli during2019/2020

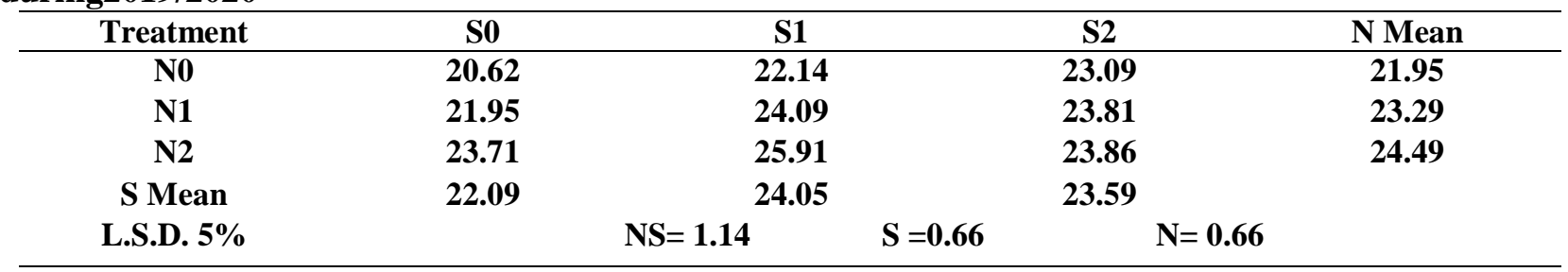

Table 4. Effects of nitrogen and sulfur levels and their interaction on leaves area $\left(\mathrm{dm}^{2} \cdot \mathrm{plant}^{-1}\right)$ of broccoli during 2019/2020.

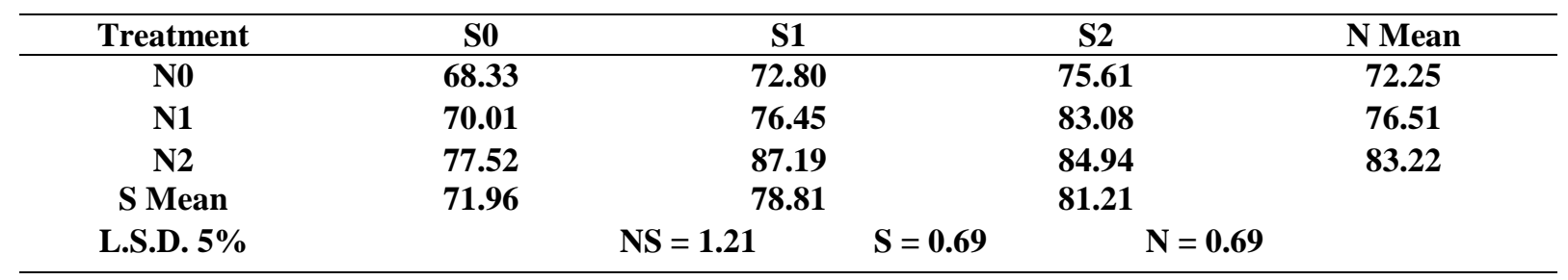

Table 5. Effects of nitrogen and sulfur levels and their interaction on leaves dry weight (gm) of broccoli during 2019/2020.

\begin{tabular}{cccccc}
\hline Treatment & S0 & S1 & S2 & N Mean \\
\hline N0 & 94.38 & & 107.91 & 117.06 & 106.45 \\
N1 & 102.65 & 122.39 & 132.49 & 119.18 \\
N2 & 121.77 & & 147.72 & 135.09 & 134.86 \\
S Mean & 106.27 & & 126.01 & 128.21 & \\
L.S.D.5\% & & NS = 3.79 & & S $=\mathbf{2 . 1 9}$ & \multicolumn{2}{c}{ N = 2.19 } & \\
\hline
\end{tabular}

Table 6. Effects of nitrogen and sulfur levels and their interaction on root fresh weight (gm) of broccoli during 2019/2020.

\begin{tabular}{|c|c|c|c|c|}
\hline Treatment & S0 & S1 & S2 & N Mean \\
\hline No & 101.59 & 111.99 & 119.59 & 111.06 \\
\hline N1 & 105.60 & 121.60 & 123.94 & 117.05 \\
\hline N2 & 107.61 & 124.99 & 124.06 & 118.89 \\
\hline S Mean & 104.94 & 119.53 & 122.53 & \\
\hline L.S.D. 5\% & & & & \\
\hline
\end{tabular}


Table 7. Effects of nitrogen and sulfur levels and their interaction on chlorophyll content index (CCI) of broccoli during 2019/2020.

\begin{tabular}{ccccc}
\hline Treatment & S0 & S1 & S2 & N Mean \\
\hline N0 & 39.41 & 43.98 & 47.88 & 43.75 \\
N1 & 47.28 & 53.49 & 60.39 & 53.72 \\
N2 & 57.36 & $\mathbf{6 4 . 8 4}$ & 59.52 & 60.57 \\
S Mean & 48.02 & $\mathbf{5 4 . 1 0}$ & $\mathbf{5 5 . 9 3}$ & \\
L.S.D. 5\% & & NS = 3.23 & S = 1.86 & N = 1.86
\end{tabular}

Table 8. Effects of nitrogen and sulfur levels and their interaction on main curd weight (gm) of broccoli plants during 2019/2020.

\begin{tabular}{ccccc}
\hline Treatment & S0 & S1 & S2 & N Mean \\
\hline N0 & 376.46 & 464.62 & 447.21 & 429.43 \\
N1 & 386.46 & 472.75 & 484.51 & 447.91 \\
N2 & 458.30 & 491.91 & 486.55 & 478.92 \\
S Mean & 407.07 & 476.43 & 472.76 & N = 5.71 \\
L.S.D. 5\% & & NS $=9.90$ & S $=5.71$ & \multicolumn{2}{c}{. } \\
\hline
\end{tabular}

\section{Discussion:}

The outcomes of the present study can be initially discussed in light of the clear effects of spraying the two macronutrient (nitrogen and sulfur) on broccoli leaves, as evident by the significant increase in the vegetative growth traits, i.e. plant height, stem diameter, leaves number per plant, leaf area, leaf dry weight, root fresh weight, as well as CCI and the main curd yield.

The significant increase in the characteristics of vegetative growth may be attributed to the improvement of the absorption of nitrogen and sulfur following their foliar spraying. This is probably due to the fact that these two elements are of great importance in many physiological and biological processes that have to do with photosynthesis and food processing in plants, as well as stimulating cell division and elongation $(22,23)$. These effects directly lead to increasing plant height, stem diameter, number and area of leaves, as well as roots growth. Such enhancement of these traits of the plant and its leaves leads to increases in photosynthesis products and in the accumulation of organic compounds, such as carbohydrates and amino acids. This impact occurs through the metabolism of sugars and the movement of other nutrients across the membranes and thus the increase of their levels in the leaves (24). These nutrients affect the processes of opening and closing of the stomata and the transpiration, which causes an increase in the absorption of elements from the soil by increasing the permeability of cell membranes. Such impacts lead to an increase in the dry weight of shoot and root systems and, thus, the yield is increased by increasing the flower disc output. (25)

The increase in chlorophyll may be attributed to the role of nitrogen in the synthesis of porphyrins, which are involved in the formation of chlorophyll molecules (26).

Among the major essential nutrients required by the plants for their normal growth, development, and yield, the role of nitrogen is very necessary for the synthesis and functions of proteins, nucleic acids, chlorophyll, and certain important enzymes $(27,28)$.

Sulfur nutrition is strongly correlated with that of nitrogen due to the need for both in protein synthesis. Thus, sulfate deficiency reduces nitrate uptake and vice versa (24). During growth, $\mathrm{N}$ and $\mathrm{S}$ nutrition are closely linked, as reflected by the reported synergetic plant uptake of sulfate and nitrate at optimum rates (29). Sulfur has become one of the most limiting nutrients in agriculture production. In plants, sulfur is involved in numerus metabolic activities, especially in amino acid and protein synthesis (24). Plants assimilate inorganic sulfate into cysteine, which is subsequently converted into methionine (30), and this reduction step is regulated by the nitrogen content (31).

Our results on vegetative growth and yield agree with those of previous studies $(32,33)$, which found that the application of nitrogen on broccoli plants significantly increases stem diameter, leave area, number of leaves per plant, leave dry weight, and yield of broccoli heads. Meanwhile, other reports $(34,35)$ on cauliflower revealed that the application of sulfur increases the plant height, number of leaves per plant, dry matter content (\%) and fresh weight of curd. The findings of an earlier work (36) are consistent with our results on broccoli, which demonstrated that optimal amounts of nitrogen and sulfur cause higher mean values of head weight. When sulfur was insufficient and nitrogen was optimal, the head weight was reduced, indicating that insufficient sulfur supply limited the utilization of nitrogen. 


\section{Conclusion:}

In conclusion, the present study draws the following: nitrogen and sulfur and their interaction enhance significantly the growth and production of broccoli. Optimum yield of broccoli is obtained when sulfur is applied at $500 \mathrm{mg} . \mathrm{l}^{-1}$ and nitrogen at $1000 \mathrm{mg} . \mathrm{l}^{-1}$, the best overlap treatment is the S1N2 (500 mg. $\mathrm{l}^{-1}$ Sulfur and $1000 \mathrm{mg} \cdot \mathrm{l}^{-1}$ Nitrogen) concentration for the local agricultural climate.

\section{Authors' declaration:}

- Conflicts of Interest: None.

- We hereby confirm that all the Figures and Tables in the manuscript are mine ours. Besides, the Figures and images, which are not mine ours, have been given the permission for republication attached with the manuscript.

- Ethical Clearance: The project was approved by the local ethical committee in University of Baghdad.

\section{References:}

1. Anonymous (2020) Broccoli, Encyclopedia Britannica.

2. FAOSTAT, $2018 \mathrm{UN}$ Food and Agriculture Organization, Corporate Statistical Database (FAOSTAT). 2018. Retrieved 27 June 2019. http://www.fao.org/faostat/en/\#data/QC.

3. Ravi kumar C. Therapeutic potential of Brassica oleracea (broccoli)-A review. Int J Drug Dev Res. 2015;7(2):009-10.

4. Liu M, Zhang L, Ser SL, Cumming JR, Ku KM. Comparative phytonutrient analysis of broccoli byproducts: The potentials for broccoli by-product utilization. Molecules. 2018 Apr;23(4):900.

5. Raiola A, Errico A, Petruk G, Monti DM, Barone A, Rigano MM. Bioactive compounds in Brassicaceae vegetables with a role in the prevention of chronic diseases. Molecules. 2018 Jan;23(1):15.

6. Qahar A, Ahmad B. Macro Nutrients (Nitrogen and Sulfur) Role in Phenology and Physiology of Different Corn Hybrids under Agro Climatic Conditions of Peshawar. Pure Appl Biol. 2015 Mar $1 ; 4(1): 89$.

7. Kaur G, Sharma M. Effect of nitrogen doses and inter crops on growth and yield of broccoli (Brassica oleracea L. var. italica). Indian J Agric Res. 2018;52(5):566-70.

8. Conversa G, Lazzizera C, Bonasia A, Elia A. Growth, $\mathrm{N}$ uptake and $\mathrm{N}$ critical dilution curve in broccoli cultivars grown under Mediterranean conditions. Sci Hortic. 2019 Jan 26;244:109-21.

9. Babik I, Elkner K. The effect of nitrogen fertilization and irrigation on yield and quality of broccoli. InWorkshop Towards and Ecologically Sound Fertilisation in Field Vegetable Production 5712000 Sep 11 (pp. 33-43).
10. Skudra I, Ruza A. Effect of nitrogen and sulphur fertilization on chlorophyll content in winter wheat. Rural Sustainability Res. 2017 Jul 1;37(332):29-37.

11. Mellgren R. Effect of irrigation and nitrogen treatments on yield, quality, plant nitrogen uptake and soil nitrogen status and the evaluation of sap test, SPAD chlorophyll meter and Dualex to monitor nitrogen status in broccoli. 2008.

12. Corrêa C, Gouveia A, Cardoso A. BROCCOLI PRODUCTION IN FUNCTION OF DOSES OF SULPHUR IN COVERAGE. Braz J Agric-Revista de Agricultura. 2019 Aug 26;94(2):144-52.

13. Farooq M, Bakhtiar M, Ahmed S, Ilyas N, Khan I, Saboor A, et al. Influence of Sulfur and Boron on the growth and yield of Broccoli. Int $\mathbf{J}$ Environ Agric Res. 2018;4(4):9-16.

14. Sanderson KR. Broccoli and cauliflower response to supplemental soil sulphur and calcium. In XXVI International Horticultural Congress: Toward Ecologically Sound Fertilization Strategies for Field Vegetable Production 6272002 Aug 11 (pp. 171179).

15. Abdallah M, Dubousset L, Meuriot F, Etienne P, Avice JC, Ourry A. Effect of mineral sulphur availability on nitrogen and sulphur uptake and remobilization during the vegetative growth of Brassica napus L. J Exp Bot. 2010 Jun 1;61(10):2635-46.

16. Slosar M, Uher A, Andrejiova A, Jurĺkova T. Selected yield and qualitative parameters of broccoli in dependence on nitrogen, sulfur, and zinc fertilization. Turk J Agric For. 2016 May 18;40(3):465-73.

17. Elwan MW, Abd El-Hamed KE. Influence of nitrogen form, growing season and sulfur fertilization on yield and the content of nitrate and vitamin $\mathrm{C}$ of broccoli. Sci Hortic. 2011 Jan 10;127(3):181-7.

18. Aghtape AA, Ghanbari A, Sirousmehr A, Siahsar B, Asgharipour M, Tavssoli A. Effect of irrigation with wastewater and foliar fertilizer application on some forage characteristics of foxtail millet (Setaria italica). Int J Plant Physiol Biochem. 2011 Mar 31;3(3):34-42.

19. Riley $\mathrm{H}$, Vågen I. Critical N-concentrations in broccoli and cauliflower, evaluated in field trials with varying levels and timing $\mathrm{N}$ fertilizer. InXXVI International Horticultural Congress: Toward Ecologically Sound Fertilization Strategies for Field Vegetable Production 6272002 Aug 11 (pp. 241249).

20. Everaarts AP, De Willigen P. The effect of nitrogen and the method of application on yield and quality of broccoli. NJAS 1999 Nov 1;47(2):123-33.

21. Dong T, Shang J, Chen JM, Liu J, Qian B, Ma B, et al. Assessment of portable chlorophyll meters for measuring crop leaf chlorophyll concentration. Remote Sens. 2019 Jan;11(22):2706.

22. Leghari SJ, Wahocho NA, Laghari GM, HafeezLaghari A, MustafaBhabhan G, HussainTalpur $\mathrm{K}$, et al. Role of nitrogen for plant growth and development: A review. Adv Environ Biol. 2016 Sep 1;10(9):209-19. 
23. Raza MA, Feng LY, Iqbal N, Manaf A, Khalid MH, Ur Rehman S, et al. Effect of sulphur application on photosynthesis and biomass accumulation of sesame varieties under rainfed conditions. Agron. 2018 Aug;8(8):149.

24. Jobe TO, Zenzen I, Rahimzadeh KP, Kopriva S. Integration of sulfate assimilation with carbon and nitrogen metabolism in transition from $\mathrm{C} 3$ to $\mathrm{C} 4$ photosynthesis. J Exp Bot. 2019 Aug 15;70(16):421121.

25. Koch M, Naumann M, Pawelzik E, Gransee A, Thiel H. The importance of nutrient management for potato production Part I: Plant nutrition and yield. Potato Res. 2020 Mar;63(1):97-119.

26. Kashiyama Y, Ogawa NO, Kuroda J, Shiro M, Nomoto S, Tada R, et al. Diazotrophic cyanobacteria as the major photoautotrophs during mid-Cretaceous oceanic anoxic events: Nitrogen and carbon isotopic evidence from sedimentary porphyrin. Org Geochem. 2008 May 1;39(5):532-49.

27. Baloch PA, Riaz U, Nizamani FK, Solangi AH, Siddiqui AA. Effect of nitrogen, phosphorus and potassium fertilizers on growth and yield characteristics of radish (Raphinus sativus L.). Am Eurasian J Agric Environ Sci. 2014;14(6):565-9.

28. Leghari SJ, Wahocho NA, Laghari GM, HafeezLaghari A, MustafaBhabhan G, HussainTalpur $\mathrm{K}$, et al. Role of nitrogen for plant growth and development: A review. Adv Environ Biol. 2016 Sep 1;10(9):209-19.

29. Samuilov S, Brilhaus D, Rademacher N, Flachbart S, Arab L, Alfarraj S, et al. The photorespiratory BOU gene mutation alters sulfur assimilation and its crosstalk with carbon and nitrogen metabolism in Arabidopsis thaliana. Front Plant Sci. 2018 Nov 27;9:1709.

30. Nikiforova V, Freitag J, Kempa S, Adamik M, Hesse H, Hoefgen R. Transcriptome analysis of sulfur depletion in Arabidopsis thaliana: interlacing of biosynthetic pathways provides response specificity. Plant J. 2003 Feb;33(4):633-50.

31. Koprivova A, Kopriva S. Molecular mechanisms of regulation of sulfate assimilation: first steps on a long road. Front Plant Sci. 2014 Oct 29;5:589.

32. Metwaly EE. Effect of Nitrogen and Boron Fertilization on Yield and Quality of Broccoli. J Plant Prod. 2016 Dec 1;7(12):1395-400.

33. Yoldas F, Ceylan S, Yagmur B, Mordogan N. Effects of nitrogen fertilizer on yield quality and nutrient content in broccoli. J Plant Nutr. 2008 Jun 18;31(7):1333-43.

34. Jamre BR, Nagaich KN, Hemlata V. Effect of different levels of sulphur and zinc on growth and yield of cauliflower (Brassica oleracea var. botrytis L.). Asian J Hort. 2010;5(2):323-5.

35. Khan OA, Raina SK, D RAM MA, MALIK M, WANI J. Effect of different sources of sulphur on yield and quality of cauliflower (Brassica oleracea) under temperate conditions of Kashmir. Indian $\mathbf{J}$ Agric Sci. 2018 Feb 1;88(2):284-8.

36. Schonhof I, Blankenburg D, Müller S, Krumbein A. Sulfur and nitrogen supply influence growth, product appearance, and glucosinolate concentration of broccoli. J Plant Nutr Soil Sci. 2007 Feb;170(1):6572 . 


\section{Brassica oleracea var. italica L. تأثير الرش بالنتروجين والكبريت على نمو وإنتاج نبات البروكلي}

نورا صاحب عبد

زينب انور علي
نبيل جواد كاظم 2

مشتاق فرج كرومي كسكو 1

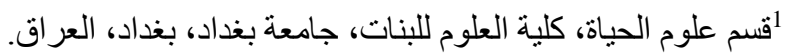

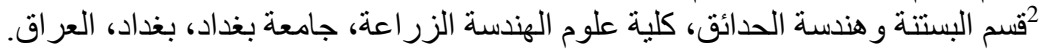
3قسم الكثف الحيوي، دائرة البيئة والمياه، وزارة العلوم الزراعة التكنولوجية، بغداد، العر اقاق.

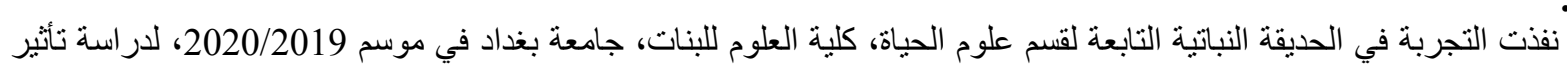

عنصري النتروجين و الكبريت وتداخلهما في النمو الخضري وخصائل

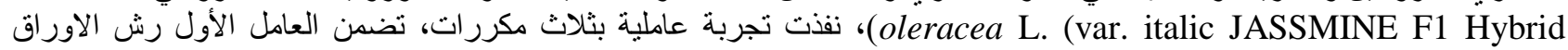

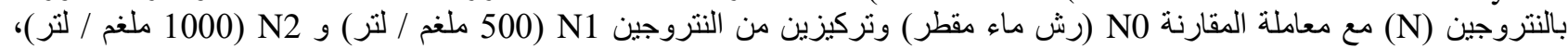

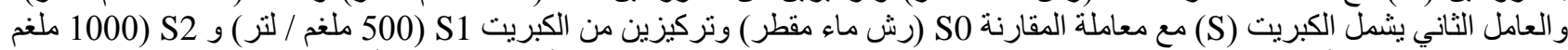

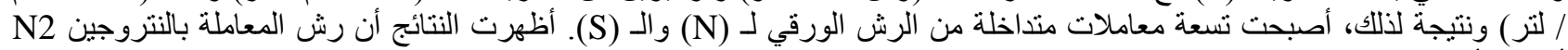

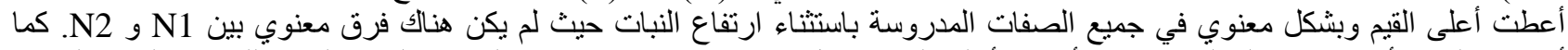

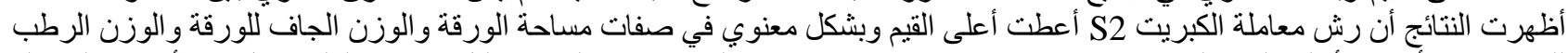

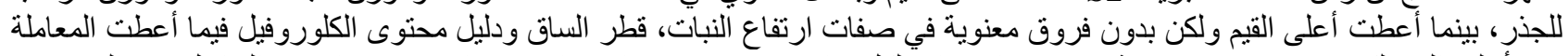

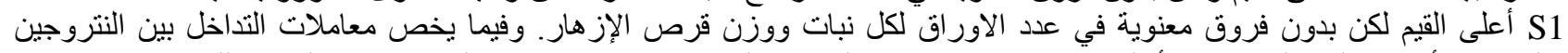

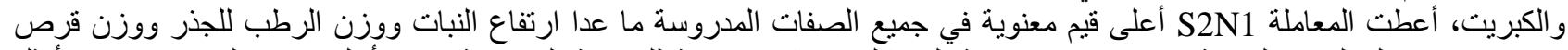

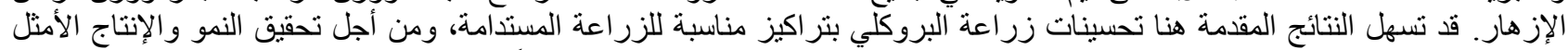

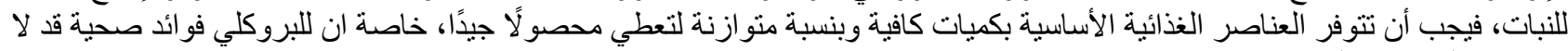
توجد في العديد من النباتات.

الكلمات المفتاحية: Brassica oleracea، بروكلي، الرش الورقي، النتروجين، الكبريت 